\title{
INDEX TO VOLUME 3
}

Aleksander, I. The effect of information technology on manufacturing, 27-30

Balachandran, K. Controllability of nonlinear perturbations of linear systems with distributed delays in control, 89-91

Bell, D. A. Employment skills for the robot age, 93-95

Bessant, John. The integration barrier; problems in the implementation of advanced manufacturing technology, 97-103

Bonfioli, M., Garetti, M. \& Pozzetti, A. Production scheduling and operational control of flexible manufacturing systems, 233-243

Braganca, C. A. J. \& Sholl, P. VAL-II, a language for hierarchical control of a robot-based automated factory, 265-272

Cantino, V. See Micheletti, Cantino \& Fenoglio.

Carrie, A. S. \& Petsopoulos, A. C. Operation sequencing in a FMS, 259-264

Carter, $\mathbf{N}$. The application of a flexible tooling system in a flexible manufacturing system, 221-228

Chilver, Sir Henry, F.R.S. Some comments on the national conference on 'The economic, social, financial and technical effects of automation' (November 27-28, 1984; University of Salford, U.K.)-Conference closure, 171-172

Datta, Ashoke Kumar. A fuzzy model for learning in automata, 39-44

De Luca, Ing. Adriano. Software tools for FMS and FAS preliminary design: an industrial case study, 273-277

Fenoglio, F. See Micheletti, Cantino \& Fenoglio

Garetti, M. See Bonfioli, Garetti \& Pozzetti

Ito, Masami. See Narikiyo \& Ito

Jumarie, G. A small parameter method to improve optimum control via the linearization technique, $85-88$

Kassler, M. Robots and mining: the implications for Australian industry in the 1980's, 13-19

Kent, E. W., Wheatley, T. \& Nashman, M. Real-time cooperative interaction between structured-light and reflectance ranging for robot guidance, $7-11$

Kirćanski, N. See Vukobratović, Li \& Kirćanski

Kusiak, A. Planning of flexible manufacturing systems, 229-232

Kusiak, A., Vannelli, A. \& Ravi Kumar, K. Grouping problem in scheduling flexible manufacturing systems, 245-252

Lenarcič, J. An efficient numerical approach for calculating the inverse kinematics for robot manipulations, 21-26

Lenarcič, J. See Nemec \& Lenarcic

Li, Shi-Gang. See Vukobratovic, Li. \& Kirćanski

Micheletti, G. F., Cantino, V. \& Fenoglio, F. An application of simulation theory in F.M.S., 253-257

Naranjo, M. See Richetin \& Naranjo

Narikiyo, Tatsuo \& Ito, Masami. Control of a biped locomotion system in a double support phase, 73-77

Nashman, M. See Kent, Wheatley \& Nashman

Nemec, B. \& Lenarčč, J. A robot simulation system based on kinematic analyses, 79-84

Nicolò, V. FMS and the main car industry, 137-145

Petsopoulos, A. C. See Carrie \& Petsopoulos

Pozzetti, A. See Bonfioli, Garetti \& Pozzetti

Ranky, P. G. Introduction to the special FMS issue, 203-204

Ranky, P. G. FMS in CIM (Flexible manufacturing systems in computer integrated manufacturing), 205-214 
Ravi Kumar, K. See Kusiak, Vannelli \& Ravi Kumar

Rayson, P. T. A review of expert systems principles and their role in manufacturing systems, 279-287

Richetin, M. \& Naranjo, M. Inference of Automata by dialectic learning, 159-163

Rudall, B. H. Towards automatic software generation, 31-34

Scott, P. B. The 'Omnigripper': a form of robot universal gripper, 153-158

Sholl, P. See Braganca \& Sholl

Taylor, I. Overall control within a flexible manufacturing system and the development of a cell controller, 215-220

Taylor, R. G. Changing needs of industrial and commercial education and training, 35-37

Tynan, $\mathbf{0}$. Change and the nature of work. Some employment and organisational problems of advanced manufacturing technology, 173-180

Vanelli, A. See Kusiak, Vannelli \& Ravi Kumar

Vukobratoviæ, M., Li, Shi-Gang \& Kirčanski, N. An efficient procedure for generating dynamic manipulator models, $147-152$

Wheatley, T. See Kent, Wheatley \& Nashman

Yonemoto, Kanji. International cooperation and trends in the field of industrial robots, 165-170 
INDEX OF BOOKS REVIEWED IN VOLUME 3

The name of the reviewer of the book is given in parentheses

Aleksander, I. \& Burnett, P. Reinventing Man. (H. M. Rosenbrock) 193-194.

Alty, J. L. \& Coombs, M. J. Expert Systems: Concepts and Examples. (J. Self) 55-56.

Bierman, A. W., Guiho, G. \& Kondratoff, Y. (Eds.) Automatic Program Construction. (I. D. CraIG) 118.

Boothroyd, G., Poli, C. \& Murch, L. E. Automatic Assembly. (K. E. MCKEe) 195-196.

Clancey, W. J. \& Shortliffe, E. H. (Eds.) Readings in Medical Artificial Intelligence: The First Decade. (A. M. ANDREw) 191.

Cotellessa, R. F. (Ed.) Identifying Research Areas in the Computer Industry to 1995. (J. A. EsRom) 118.

Danthine, A. \& Géradin, M. (Eds.) Advanced Software in Robotics. (A. M. Andrew) 192.

Forsyth, R. (Ed.) Expert Systems: Principles and Case Studies. (J. Self) 55-56.

Grayson, C. Jackson Jr., Goshi, K. \& Tippet, P. Strategies for Productivity: International Perspectives. (K. E. MCKeE) 196

Hudson, P. R. W. (Ed.) Proceedings of the Second National Conference on Wool Harvesting Research and Development. (J. EsROM) 56.

Phillips, J. Freedom in Machinery_Vol. 1 Introducing Screw Theory. (M. J. Gilmartin) 194.

Ponomaryov, V.M. (Ed.) Artificial Intelligence: Proceedings of the IFAC Symposium, Leningrad, USSR, 1983. (A. M. ANDREW) 117-118.

Proceedings of the International Conference on Advances in Manufacturing. (A. J. LOADER) 194-195.

Proceedings of the 1st International Conference on Machine Control Systems. (D. A. BRADLEY) 193.

Proceedings of the 6th International Congress of Cybernetics and Systems of the W.O.G.S.C. Organized by the Collège De Systèmique De L'Afcet, 10-14 September 1984 Paris. (E. NiCOLAU) 194.

Pylyshyn, Z. W. Computation and Cognition: Towards a Foundation for Cognitive Science. (A. M. ANDREW) 191-192.

Riley, F. J. Assembly Automation: A Management Handbook. (K. E. McKeE) 195

Simons, G. L. Introducing Artificial Intelligence. (A. M. ANDrEw) 117

Turner, R. Logics for Artificial Intelligence (Artificial Intelligence Series). (A. M. ANDREw) 192-193.

Weiss, S. M. \& Kulikowski, C. A. A Practical Guide to Designing Expert Systems. (J. Self) 55-56. 


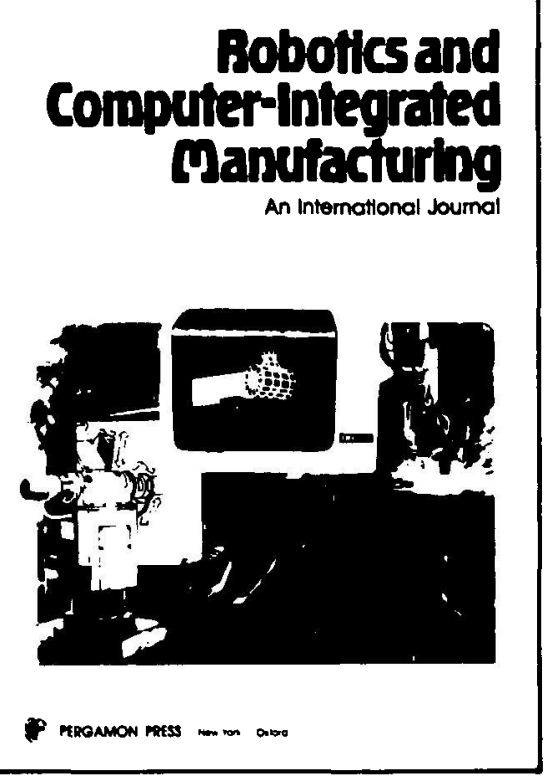

Robotics \& Computer-Integrated

Manufacturing provides an international forum for the exchange of ideas between engineers and computer scientists in industry, government and academia. The journal features original papers on theoretical, experimental and applied robotics and computer-integrated manufacturing with an emphasis on flexible manufacturing systems. Although technological aspects are uppermost, the socio-economic aspects of automated manufacturing and production are given due consideration. Papers are welcomed for editorial consideration, and should be sent to the address shown above.

New Patents Section - The journal now contains abstracts and illustrations of recently issued United States Patents and published patent applications filed from over 30 countries under the Patent Cooperation Treaty.

Software Survey Section - This new section reports developments in appropriate specialist software.

Subscription Information

Published quarterly (Volume 3)

Annual subscription (1986)

US\$125.00

Two-year rate (1986/87)

US $\$ 237.50$

\section{ROBOTICS \& COMPUTER- INTEGRATED MANUFACTURING}

\section{An International Journal}

Editors-in-Chief: N P SUH, Laboratory for Manufacturing and Productivity, MIT, Cambridge, MA 02319, USA, T SATA, Dept. of Precision Machinery Engineering, University of Tokyo, 7-4-1 Hongo Bunkyo-ku, Tokyo, Japan, and G SPUR, Institute of Machine Tools and Manufacturing Technology, Technical University of Berlin, Fasanenstrasse 90, 1000 Berlin 12, FRG

The journal covers the following areas: Computer languages and architectures Graphics

Artificial intelligence and expert systems In-process metrology

System integration

Interface standards

Manipulators and end-effectors

$\mathrm{CAD} / \mathrm{CAM} / \mathrm{CAT}$

Controls systems

Robot related research

Product control and reliability

High precision engineering and factory automation

Manufacturing systems modeling simulation

Sensors, signal processing and pattern recognition

Machine tool error reduction using computer controlled compensation Process planning

Conceptual designs of future factories Production scheduling and inventory control

Environmental, human and economic factors

\section{Pergamon Press}

Headington Hill Hall, Oxford OX3 OBW. UK Fairview Park, Elmsford, New York 10523, USA 


\section{New from MIT}

Artificial Intelligence Series, edited by Patrick Winston and Michael Brady

\section{Legged Robots That Balance}

\section{Marc H. Raibert}

Marc Raibert's unique work on legged locomo. tıon presents excitıng engineering and science. along with fascinatıng implications for theories of human motor control. This book describes the study of physical machınes that run and balance on just one leg. including analysis. computer simulation. and laboratory experiments it describes how the principles of locomotion discovered with one leg can be extended to systems with several legs and reports prelımınary experıments with a quadruped machine that runs usıng these princıples $\$ 3000$

\section{The Acquisition of Syntactic Knowledge}

\section{Robert Berwick}

This landmark work in computational linguis. tics is of great importance both theoretically and practically because it shows that much of English grammar can be learned by a simple program $\$ 2750$

\section{Theory and Practice of Robots and Manipulators}

Proceedings of RoManSy 1984 the Fifth CISM-IFToMM Symposium edited by A. Morecki, G. Bianch, and K. Kedzior

Now more than a decade old. the RoManSy meetıngs on robotıcs focus primarily on mechanical engineerıng and control. drawing heavily on work in Eastern Europe and the USSR Workıng papers cover mechanics. control of motion. synthesis and design. biomechanics of motion-locomotion man-intel. lıgent machıne systems. application and performance evaluation

$\$ 4500$

\section{Performance and Evaluation of LISP Systems}

Richard P. Gabriel

This final report of the Stanford LISP Perform. ance Study describes implementation tech. nıques. performance tradeoffs. benchmarkıng techiques. and performance results for all of the major LISP dialects in use today Computer Systems Series. Research Reports and Notes. edited by Herb Schwetman

$\$ 2250$ Softcover

28 Carleton Street Cambridge, MA 02142 
Just Published...

... in the "ICCP" (Information, Computer, Communication Policy) Series:

\section{No. 9: SOFTWARE: An Emerging Industry}

OECD, has just published the first thorough study of one of the most dynamic of today's fastgrowing fields.

SOFTWARE: An Emerging Industry.

Part one. "Technology and Industrial Organisation", surveys the main types of software and their varying life cycles as well as the growth and development of the specialised industry devoted to its production. The particular cases of embedded micro-electronics and industrial automation software are also analysed.

The second part, "The Role and Action of Governments" studies official research and training policies, government software procurement, standardisation issues, the role of telecommunications infrastructures and implications for software of industrial policies in the hardware industry. Growth problems in software firms and government support in several OECD countries are also considered.
Foreign trade regulations and legal aspects of software are examined and numerous tables and graphs are presented in Annex.

208 pages. ISBN 92-64-12755-0

f12.00 US $\$ 24.00$ F120.00 DM53.00 . . . . copylies) VENTURE CAPITAL IN INFORMATION TECHNOLOGY

Venture capitalism, an expanding form of financial intermediation in the United States, has accounted for most of the innovative and successful company start-ups in industries and services based on information technology.

This field, in turn, has been the prime target for venture capital activity. The potential for extension of venture capitalism beyond the United States is examined.

54 pages, ISBN 92-64-12696-1

E5 50 US\$11.00 F55.00 DM25.00 . . . . . copylies)

OECD Catalogue of Publications:

Free on request ........... copy(ies)

Please indicate quantity of each publication and send your order with your business card to:

UK Customers:

HMSO Books PC16, Publications Centre, 51 Nine Elms Lane, London SW8 5DR

\section{Other Countries: (DIST)}

ORGANISATION FOR ECONOMIC CO-OPERATION AND DEVELOPMENT 


\section{Notes for Contributors}

1. Manuscripts should preferably be written in English, but papers in French and German will also be accepted. All manuscripts will be referred to acknowledged experts in the subject. Only those receiving favourable recommendations from the referees will be accepted for publication. Manuscripts may be sent to any Board member, any Deputy Editor or the Editor.

2. Typescripts should be double spaced, on one side of good grade paper, allowing a reasonable left-hand margin. An original and two copies should be submitted with the author's full postal address, position and affiliations.

3. A short abstract of about 80 words should precede the main text. List of symbols: A typewritten list of any special symbols should be submitted with the manuscript. The list should not define the symbols mathematically, but should serve to identify them typographically. The list will not appear in print, but is essential to help the typesetter and to avoid costly correction in proof.

4. One copy of photographs, prints or transparencies of good quality and unmarked should be submitted. Where lines or lettering are to appear on the photograph, an additional print should be supplied appropriately marked. Each should have; lightly written on the back, the author's name, the figure number and an indication of which is the top of the picture.

5. One copy of each line diagram should be submitted at approximately twice final size and unlettered. Diagrams must be drawn in indian ink on plain white or transparent paper. A second copy should be supplied with lettering included. The author's name and the figure number should be written on this copy. Figures should be numbered consecutively, with arabic numerals, have descriptive captions, and be mentioned in the text. The correct position for each figure should be indicated in the margin of the manuscript.

6. Tables should be typewritten on separate sheets. Avoid, where possible, very wide tables. Number tables consecutively with roman numerals. Each should have a brief heading. Exceptionally lengthy tables may be summarized for publication with a note that copies of details can be obtained from the authors.

7. Equations: Wherever possible, mathematical equations should be typewritten, with subscripts and superscripts clearly indicated. The printer will set all mathematical symbols in italics unless otherwise indicated; symbols or letters to be set in roman (upright) type should be encircled in pencil, while bold letters should be shown by a wavy underline.

8. References: In the text, references are indicated by superior arabic numbers (without brackets), and should be confined to publish work that is directly pertinent. References should be listed at the end of the paper in numerical order. Authors' initials should precede their names; cited article titles should be quoted in full, enclosed in quotation marks; and abbreviations of journal names should follow the style of Chemical Abstracts or Physical Abstracts, and be underlined for italics: P.W. Anderson, "More is different" Science 177, 393 (1972) C.V. Negoita, Fuzzy Systems (Abacus Press, Tunbridge Wells, UK, 1980)

Citations such as 'personal communication', 'unpublished work', etc., are not acceptable as numbered references but can be included in parenthesis in the text. Do not use summaries as references.

9. Proofs: Page proofs will be sent to authors for correction, for return within 48 hours by airmail. Correction to proofs should be restricted to printers' errors only. Authors are entitled to 25 offprints of their article free of charge. Additional offprints may be purchased if they are ordered on the form sent with the proofs.

10. Manuscripts, whether accepted or rejected, will not be returned to the authors.

11. Submission of an article will be taken to imply that it has not been previously published and that it is not on offer to any other publisher. 


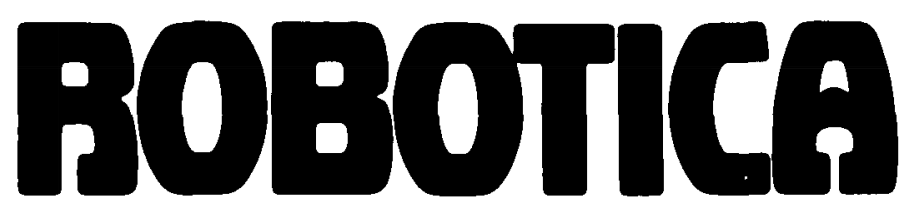

Volume 4 Part 1

January-March 1986

\section{CONTENTS}

Reports and Surveys, (Automation at Jaguar Cars, Automation in the Office, Education and training, Computers new Developments, Compiler chip, High Technology Companies in the U.S. and the U.K., Machine Vision, New Application for Automation, New Products and Projects, Software Reports, Reports on Japanese Industries, Robots Worldwide, Trade Unions and the New Technology, U.S. Productivity Survey and Reports) B. H. Rudall (U.K.)

Distributed manufacturing systems, R. H. Weston, C. M. Sumpter and J. D. Gascoigne (U.K.)

The induced vibration touch sensor-a new dynamic touch sensing concept, Robert W. Patterson and Gale E. Nevill, Jr. (U.S.A.)

Flexible production organization of workpiece movement, J. F. Coudurier (France)

Contribution to a computer-aided choice of D.C. motors for manipulation robots, V. Potkonjak and N. Jakšić (Yugoslavia)

Some principles for robotics based on general automata, Eldo C. Koenig (U.S.A.)

Automation and Maintenance Training, Peter Senker (U.K.)

Manpower and Training problems in the U.K., J. Wiltshire (U.K.) 51

$\begin{array}{ll}\text { Conference Reports } & 55\end{array}$

$\begin{array}{ll}\text { Book Reviews } & \mathbf{6 1}\end{array}$

$\begin{array}{ll}\text { Special Feature } & 64\end{array}$

$\begin{array}{lr}\text { Announcements } & 65\end{array}$ 